\title{
Harvest date and fertilizer effects on native and interseeded wetland meadows
}

\author{
P.E. REECE, J.T. NICHOLS, J.E. BRUMMER, R.K. ENGEL, AND K.M. ESKRIDGE
}

P.E. Reece, Dept. of Agronomy, Univ. of Nebraska Panhandle Research and Extension Center, 4502 Avenue I, Scottsbluff 69361; J.T. Nichols, J.E. Brummer, and R. K. Engel, Dept. of Agronomy, Univ. of Nebraska West Central Research and Extension Center, Route 4, Box 46A, North Platte 69101; and K.M. Eskridge, Dept. of Biometry, Univ. of Nebraska, 103 Miller Hall, Lincoln 68583.

\begin{abstract}
Studies of harvest date by fertilizer interactions on hay meadows are rare and none have been published for prairie meadows. Our objective was to evaluate the effects of initial harvest date (15 June, $15 \mathrm{July}$, and 15 August) and spring-applied $N(0,45,90$, and $135 \mathrm{~kg}$ $h^{-1}$ ) on first cutting and regrowth dry matter yield and forage quality from native and interseeded wetland meadow sites. Regrowth was harvested on all plots in late September. 'Garrison' creeping foxtail (Alopecurus arundinaceus Poir.) was interseeded on plots 4 years prior to application of treatments. Native vegetation was dominated by sedges (Carex spp.). Interseeded plots were dominated by Garrison creeping foxtail.

Yield and quality on different dates and response to $\mathbf{N}$ were similar for vegetation types despite differences in duration of spring flooding between years. Harvest date by fertilizer interactions occurred for first cutting yield and crude protein concentration. Yield response to applied $\mathrm{N}$ ranged from 8.5 to $31.2 \mathrm{~kg} \mathrm{ha}^{-1}$ $\mathrm{kg}^{-1} \mathrm{~N}$. Fertilizer had no effect on digestibility and increased crude protein concentration only in herbage harvested on 15 June. Within levels of $\mathbf{N}$, first cutting yield was about $60 \%$ of peak standing crop on 15 June and $90 \%$ on 15 July compared with 15 August. Greater plant growth rates and response to $\mathbf{N}$ after prolonged spring flooding compensated for initial differences between years by 15 July. Regrowth dry matter yield was not affected by spring-applied $N$ and increased by about $43 \mathrm{~kg} \mathrm{ha}^{-1} \mathrm{day}^{-1}$ after initial harvest in both years. Sedge-dominated, prairie meadows are productive and provide predictable forage and wildlife habitat management alternatives.
\end{abstract}

Key Words: Alopecurus arundinaceus, Carex nebraskensis, Carex spp., nitrogen fertilizer, herbage yield and quality, regression models

Published information on yield and quality of herbage from sedge (Carex spp.) dominated wetland meadows is limited to high elevation locations (Taylor et al. 1985). Most prairie wetland meadows provide critical sources of herbage for beef cattle and wildlife. Wetlands have become a focal point of state and federal governments (Chancey et al. 1990). Information on combinations of management practices is needed to provide a better foundation for pending legislation on wetlands. Knowledge of harvest date by $\mathbf{N}$ fertilizer interactions is needed to improve hay production efficiency and to enhance wildlife habitat management. Additionally, 'Garrison' creeping foxtail (Alopecurus arundinaceus Poir.) has been widely recommended for seeding on wetlands in the Northern and Central Great Plains for increased dry matter yield (Stroh et al.

Published as Paper \#10257, Journal Series, University of Nebraska Agricultural Research Division.

The authors wish to thank Gordon D. Moeller for technical assistance and Sharon Holman for manuscript preparation.

Manuscript accepted 18 Dec. 1993
1978, Fairbourn 1982, Dodds and Vasey 1985, Anderson et al. 1990), but comparative yield and quality studies of interseeded Garrison creeping foxtail and native vegetation on sedge dominated wetland meadows have not been reported.

Harvest dates on wetland meadows in the Nebraska Sandhills depend upon a seasonally variable water table. Equipment access and drying conditions for hay occur after the water table has dropped $10 \mathrm{~cm}$ or more below the soil surface. Water tables are 20 to $60 \mathrm{~cm}$ closer to the soil surface during much of the growing season on wetland meadows compared with subirrigated meadows in the Sandhills. Natural spring flooding occurs for 30 to 60 days on wetland meadows. Flooding is uncommon on subirrigated meadows and lasts 2 weeks or less. Normal harvest dates for wetland meadows range from mid-June to mid-August. Regrowth after haying provides a valuable source of high quality forage for livestock and many wildlife species. This study was conducted to quantify dry matter yield and forage quality on a prairie wetland meadow over a range of harvest dates and levels of spring-applied $\mathrm{N}$. First cutting and regrowth herbage was harvested from sedge dominated native vegetation and plots interseeded with Garrison creeping foxtail in 1987 and 1988. Herbaceous species encountered in this study are common to wetland meadows and are widely distributed in Canadian provinces and temperate environments in the U.S. (GPFA 1986).

\section{Materials and Methods}

\section{Site}

The study was conducted over a range of soil organic matter content and depth to water table conditions on a wetland located at the University of Nebraska, Gudmundsen Sandhills Laboratory, $11 \mathrm{~km}$ northeast of Whitman, Nebr. Soil at the study location was classified as a Gannett-Loup fine sandy loam (coarse-loamy, mixed mesic Typic Haplaquolls) derived from eolian sand parent material. Selected soil properties at the study site are presented in Table 1.

Table 1. Soil characteristics $(0-15 \mathrm{~cm})$ at the Gudmundsen Sandhills Laboratory, Laboratory, Whitman, Nebr. in 1987. ${ }^{1}$

\begin{tabular}{|c|c|c|c|c|c|c|}
\hline Block ${ }^{2}$ & $\mathrm{pH}$ & $\begin{array}{c}\text { Organic } \\
\text { matter }\end{array}$ & P(Bray-1) & $\mathbf{K}$ & $\mathrm{NO}_{3}-\mathrm{N}$ & $\mathrm{SO}_{4} \mathrm{~S}$ \\
\hline & & $(\%)$ & $\ldots \ldots$ & $-\ldots($ & n) $\ldots$ & $\ldots$ \\
\hline 1 & 6.4 & 17.6 & 7.5 & 128 & 2.1 & 6.5 \\
\hline 2 & 6.4 & 23.8 & 6.0 & 112 & 3.1 & 10.9 \\
\hline 3 & 6.8 & 31.0 & 3.1 & 141 & 2.5 & 14.7 \\
\hline
\end{tabular}

${ }^{1}$ Values are the means of 6 soil cores from cach block.

2Depth to water table declined from block 1 to block 3 . 
Soil water was not a limiting factor during the study because of natural subirrigation. Soils were water-saturated at the surface when plants initiated growth in the spring. The water table was within the rooting zone throughout the growing season. Average annual precipitation is $54.9 \mathrm{~cm}$ with $70 \%$ occurring from April through July. The average frost free period is 130 days and elevation is $1,050 \mathrm{~m}$ (NOAA 1988).

\section{Design and Treatments}

A split-split plot experimental design was used with the whole plots randomly set out into 3 complete blocks. The criterion for blocking was slope position within the wetland basin. Degree of soil wetness, duration of flooding, and proximity to the water table increased downslope. Plot dimensions were $4.9 \times 36.6 \mathrm{~m}, 4.9 \times$ $12.2 \mathrm{~m}$, and $4.9 \times 2.4 \mathrm{~m}$ for main, split, and split-split plots, respectively. Main plots were contiguous vegetation types consisting of native vegetation or interseeded to creeping foxtail. Split plots were initial harvest dates including $15 \mathrm{June}, 15 \mathrm{July}$, or 15 August. Regrowth was harvested in a second cutting on all plots at the end of the growing season on 22 September in both years of the study. Split-split plots were fertilizer treatments including control with no fertilizer, and $0,45,90$, or $135 \mathrm{~kg} \mathrm{~N}^{-1}$ each with $45 \mathrm{~kg}$ $\mathrm{P}_{2} \mathrm{O}_{5}$ ha $^{-1}$ and $23 \mathrm{~kg} \mathrm{Sha}^{-1}$. Uniform application of $\mathrm{P}$ and $\mathrm{S}$ with all levels of $\mathrm{N}$ was based upon prior research results on a subirrigated meadow (Nichols et al. 1990). Fertilizer was broadcast on the same plots $(2.4 \times 4.9 \mathrm{~m})$ in May 1987 and 1988 when the water table dropped below the soil surface. Fertilizer sources were ammonium nitrate $(34-0-0)$, triple super phosphate $(0-46-0)$, and granulated sulfur $(90 \% \mathrm{~S})$.

Four years before this experiment began, main plots were sprayed with glyphosate [N-(phosphonomethyl) glycine] at $2.8 \mathrm{~kg}$ $\mathrm{ha}^{-1}$ on 9 September 1983. Garrison creeping foxtail was then interseeded with a John Deere 1550 Power-till drill ${ }^{1}$ at $3.4 \mathrm{~kg}$ pure live seed $\mathrm{ha}^{-1}$ on 15 September 1983. All plots were hayed with adjacent wetland and subirrigated sites in early August 1984-1986. Fertilizer was not applied to the research sites until the initiation of treatments in 1987.

\section{Vegetation Types}

Basal area of plant species was measured on all native and interseeded plots 9-11 June 1987 with a 10-point frame at 10 random locations within each main plot. Total plant basal area was similar for native and interseeded plots. Plant stem bases covered about $59 \%$ of the soil surface. Native vegetation was dominated by sedges whereas interseeded plots were dominated by Garrison creeping foxtail (Table 2). Five sedge species occurred in the native vegetation: Bebb sedge [Carex bebbii (Bailey) Fern.], Crawe sedge (C. crawei Dew.), Hayden sedge ( $C$. haydenii Dew.), Nebraska sedge ( $C$. nebraskensis Dew.), and slender sedge ( $C$. praegracilis W. Boott.) Sedges produced $70 \%$ or more of the herbage harvested from native plots.

Herbicide treatment in 1983 before interseeding eliminated Nebraska sedge and reduced the relative abundance of the remaining sedge species. Sedge species accounted for $22 \%$ of basal cover on interseeded plots. Collectively, common rush (Juncus effusus L.) and compressed spikerush (Eleocharis compressa Sulliv.) composed $19 \%$ of the total plant basal area on both vegetation types. Garrison creeping foxtail composed $42 \%$ of the basal area on interseeded plots and produced $60 \%$ or more of the herbage harvested at a $5-\mathrm{cm}$ cutting height. Basal area composition for other species was similar for vegetation types except for bluejoint reedgrass [ Calamagrostis canadensis (Michx.) Beauv.], which was 6\% on native but less than $1 \%$ on interseeded plots.

\footnotetext{
The use of trade names in this article does not imply endorsement by the Nebraska
} Agr. Res. Div. of the products named, nor criticism of similar ones not mentioned.
Table 2. Mean percent of total plant basal area for species on native and interseeded wetland meadow plots 10 June 1987 at the Gudmundsen Sandhills Laboratory, Whitman, Neb.

\begin{tabular}{lcc}
\hline \hline Species & Native & Interseeded \\
\hline & 0 & 42 \\
Alopecurus arundinaceus Poir. & 13 & 0 \\
Carex nebraskensis Dew. & 41 & 22 \\
Carex bebbii (Bailey) Fern, C. crawei Dew., & & \\
C. haydenii Dew., and C. praegracilis W. & & \\
Boott. & 19 & 19 \\
Juncus effusus L., and Eleocharis compressa & & \\
Sulliv. & 10 & 8 \\
Agrostis stolonifera L. & 6 & 4 \\
Poa pratensis & 6 & $\mathrm{~T}^{2}$ \\
Calamagrostis canadensis (Michx.) Beauv. & 1 & 1 \\
Spartina pectinata Link. & 1 & $\mathrm{~T}$ \\
Phleum pratense L. & $\mathrm{T}$ & 1 \\
Trifolium pratense L. & 3 & 3 \\
Miscellaneous forbs &
\end{tabular}

'Nomenclature of plants follows the Great Plains Flora Association (1986).

${ }^{2}$ Recorded at less than $1 \%$.

\section{Sampling}

Standing crop weight from each treatment was obtained by harvesting an area $0.9 \times 4.5 \mathrm{~m}$ at a $5-\mathrm{cm}$ cut ting height. Subsamples were obtained from the harvested material, oven dried at $60^{\circ} \mathrm{C}$ to a constant weight and used to convert yield values to a dry matter (DM) basis. Subsamples were analyzed for total $\mathrm{N}$ concentration using the Kjeldahl method (AOAC 1975) and for in vitro dry matter digestibility (IVDMD) according to procedures outlined by Marten and Barnes (1980). Crude protein (CP) was estimated as the product of Kjeldahl-N multiplied by 6.25 .

Apparent uptake of applied $\mathrm{N}$ was estimated by dividing the product of DM yield and CP concentration by 6.25 , less estimated $\mathrm{N}$ uptake on $0 \mathrm{~kg} \mathrm{~N}^{-1}$ plots. Yield responses to $\mathrm{N}$ fertilizer on initial harvest dates were expressed as marginal yield responses and estimated by subtracting mean DM yield at $0 \mathrm{~kg} \mathrm{~N} \mathrm{ha}^{-1}$ from mean yields for each level of $\mathrm{N}$ and dividing by the respective application rate.

\section{Analysis}

Data were analyzed as a split-split-split plot in time over years for dry matter yield, protein concentration, and digestibility. The level of significance selected for treatment effects was $P \leq 0.05$. Initial analysis of variance included all 5 fertilizer treatments. Contrasts were used to determine if $\mathbf{P}$ and $\mathbf{S}$ had a measurable effect on DM yield and quality by comparing control and (no fertilizer) with $0 \mathrm{~kg} \mathrm{~N} \mathrm{ha}{ }^{-1}$, which included $P$ and $S$. Phosphorus and $S$ had little or no effect on yield or quality of herbage harvested from this wetland meadow. The analysis of variance presented here includes only the 4 levels of $\mathrm{N}$ fertilizer $\left(0,45,90\right.$, and $\left.135 \mathrm{~kg} \mathrm{~N} \mathrm{ha}^{-1}\right)$ to which $P$ and $S$ were uniformly applied. Single degree of freedom contrasts were used to test for significant linear and quadratic responses to initial harvest date and linear, quadratic and cubic responses to $\mathrm{N}$ level (Snedecor and Cochran 1967). When initial harvest date by year or $\mathbf{N}$ by year interactions occurred, single degree of freedom contrasts were used to test for significant differences in coefficients of regression equations between years. Dry matter yield, CP concentrations, and IVDMD models were based on the analysis of variance. Mean response values for treatments within each of the 3 blocks were used to calculate regression equations.

\section{Results and Discussion}

Wetland sites occur on the lowest benches of hay meadows in the 
Table 3. Regression equations for initial harvest date (D), $N$ fertilizer ( $N$ ), and year ( $Y$ ) interaction effects on DM yield and CP concentration on a wetland meadow at the Gudmundsen Sandhills Laboratory, Whitman, Neb.

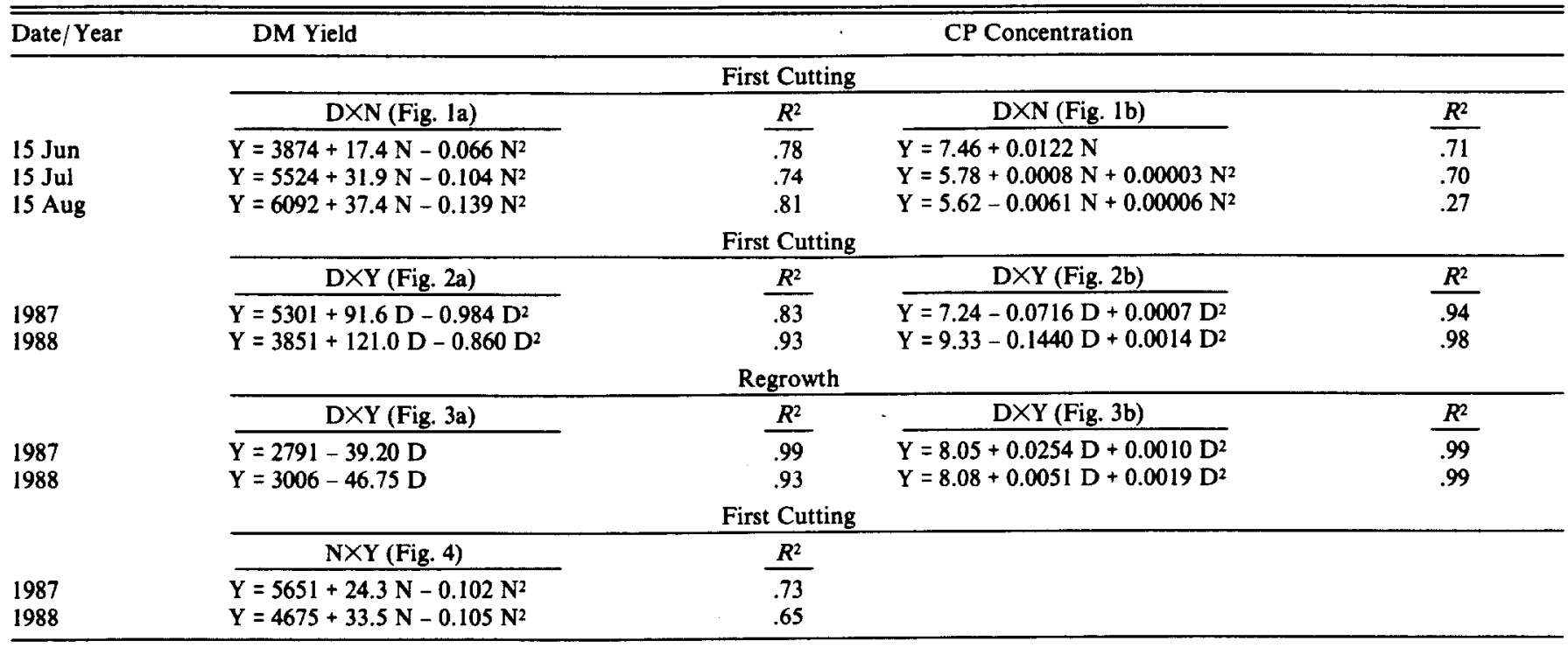

IMean DM yield and CP concentration values for initial harvest date or levels of $\mathrm{N}$ fertilizer in each of 3 blocks were used to calculate regression equations.

Sandhills. About $20.8 \mathrm{~cm}$ of precipitation occurred during the first 2 weeks of May 1988 compared with a long-term average of $8.9 \mathrm{~cm}$ for the entire month of May. Thus the water table was above the soil surface about 2 weeks longer in 1988 than 1987 and plant maturity was delayed in 1988. Cumulative precipitation from June through September was similar to the long-term average in both years.

\section{Vegetation Types}

Sedge-dominated vegetation and plots interseeded to Garrison creeping foxtail were not statistically different in dry matter yield or forage quality. Comparison of vegetation types in this study involved limited degrees of freedom with vegetation as main plots. However, evaluation of initial harvest dates, $\mathrm{N}$ fertilizer, and interaction effects with vegetation types involved progressively larger degree of freedom. Differences in yield and forage quality among initial harvest dates, response to applied $\mathrm{N}$, and interaction effects were consistent over both vegetation types. Similar yield response to fertilizer at both vegetation types in our study from 45 to $135 \mathrm{~kg}$ $\mathrm{N} \mathrm{ha}^{-1}$ concurred with a summary of 39 high elevation, intermountain meadow trials by Taylor et al. (1985).

Mean unfertilized, first-cutting DM yield in our study ranged from $3,870 \mathrm{~kg} \mathrm{ha}^{-1}$ on 15 June to $6,090 \mathrm{~kg} \mathrm{ha}^{-1}$ on 15 August (Table 3 , Fig. la). Dry matter yields in our study were high compared with a range in average yield of 1,500 to $3,400 \mathrm{~kg} \mathrm{ha}^{-1}$ reported for unfertilized wetland meadows (Gomm 1978, Welty et al. 1981, Laughlin et al. 1984, Taylor et al. 1985). Relatively low yields reported for wetland meadows may be associated with differences in the length of growing season and species composition because most sites discussed in the literature are high elevation meadows. Flooding characteristics can also affect the composition and relative productivity of wetland plant species. Rumburg and Sawyer (1965) reported that yield of rushes (Juncus spp.) increased and yield of sedges (Carex spp.) and grasses decreased with increased depth and duration of flooding. Slender sedge (Carex praegracilis $W$. Boott.) yield was greater in moist compared to saturated soils while reed canarygrass (Phalaris arundinacea L.) was most productive in saturated soils (Gomm 1978). Garrison creeping foxtail is adapted to a wide range of habitats including sites favorable for reed canarygrass (Stroh et al. 1978). Garrison creeping foxtail may be more productive than native vegetation on sites with deeper
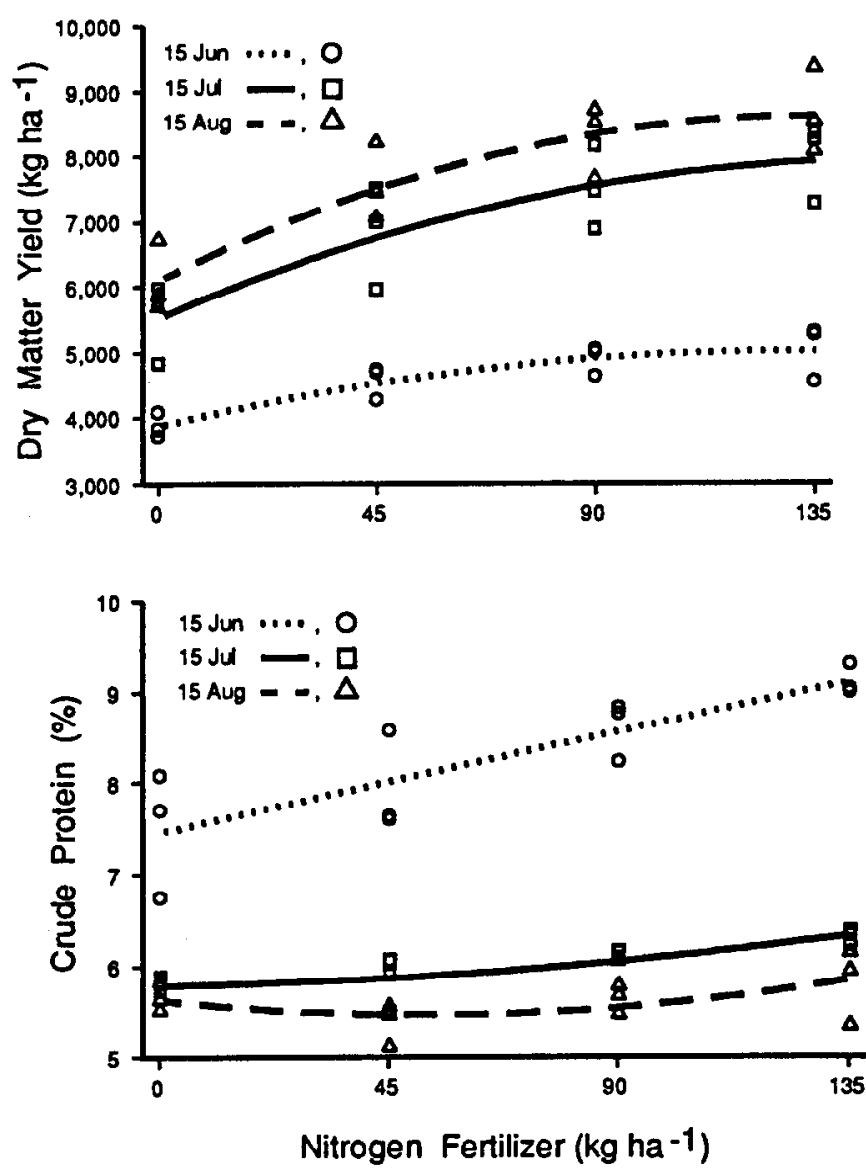

Fig. 1. Initial harvest date by $\mathbf{N}$ fertilizer effects on first cutting $D M$ yield (a) and CP concentration (b). 
floods or longer flood periods, typical of sites dominated by rushes.

\section{Harvest Date $\times$ Fertilizer}

Differences in herbage production from mid-June to midAugust increased as the level of applied $\mathbf{N}$ increased (Fig. 1a). However, within fertilizer levels, dry matter yield was about $60 \%$ of peak standing crop on 15 June and about $90 \%$ on 15 July relative to the yield response on 15 August (Fig. 1a). At $0 \mathrm{~kg} \mathrm{~N}^{-1}$ the difference in yield between $15 \mathrm{June}$ and $15 \mathrm{July}$ was about $1,640 \mathrm{~kg}$ $\mathrm{ha}^{-1}$ compared with $2,930 \mathrm{~kg} \mathrm{ha}^{-1}$ at $135 \mathrm{~kg} \mathrm{~N} \mathrm{ha}^{-1}$. Differences in yield between mid-July and mid-August were relatively small compared with the preceding 30-day period (Fig. 1a). Main effects associated with initial harvest date accounted for 55 to $77 \%$ af the total variance in the forage quality and yield of first cutting herbage and 34 to $91 \%$ of total variance in regrowth herbage. Dry matter yield response to $\mathrm{N}$ on $15 \mathrm{July}$ was comparable to fertilizer effects on subirrigated sites reported by Nichols et al. (1990).

Relative to 15 August, 84 to $90 \%$ of the apparent uptake of applied $\mathrm{N}$ in herbage occurred by $15 \mathrm{June}$, but only $46 \%$ of the marginal dry matter yield response to fertilizer occurred by 15 June (Table 4). Percent of apparent N uptake on 15 July was 97 to $100 \%$

Table 4. Estimated first cutting mar ginal $D M$ yield response to $\mathbf{N}$ fertilizer on 15 June, 15 July, and 15 August on a wetland meadow at the Gudmundsen Sandhills Laboratory, Whitman, Nebr.

\begin{tabular}{|c|c|c|c|}
\hline \multirow[b]{2}{*}{$\mathrm{N}$} & \multicolumn{3}{|c|}{ Initial harvest date } \\
\hline & 15 Jun & $15 \mathrm{Jul}$ & $15 \mathrm{Aug}$ \\
\hline & $\ldots \ldots$ & $\mathrm{ha}^{-1} \mathrm{~kg}^{-}$ & - - - - \\
\hline 45 & 14.4 & 27.1 & 31.2 \\
\hline 90 & 11.5 & 22.4 & 24.9 \\
\hline 135 & 8.5 & 17.8 & 18.6 \\
\hline
\end{tabular}

relative to 15 August and ranged from 202 to $266 \mathrm{~g} \mathrm{~kg}^{-1} \mathrm{~N}$ at 135 and $45 \mathrm{~N} \mathrm{ha}^{-1}$, respectively. The average amount of apparent $\mathrm{N}$ uptake in herbage harvested from wetland meadow sites in this study on 15 July was about $13 \%$ greater than estimated uptake on subirrigated sites reported by Nichols et al. (1990). Under dryland conditions, $\mathbf{N}$ uptake in perennial grass herbage at the end of the growing season generally accounts for less than $30 \%$ of the applied fertilizer N (Power 1988). Relatively large quantities of applied N are often immobilized in root biomass on grasslands soon after fertilization (Power 1986). A highly labile soil pool, probably including microbial biomass, can also mineralize 50 to $100 \mathrm{~kg} \mathrm{~N}$ $\mathrm{ha}^{-1}$ in a short period of time (Power 1988). Fate of $\mathrm{N}$ fertilizer has not been reported for wetland meadows.

Marginal yield responses ranged from 8.5 to $31.2 \mathrm{~kg} \mathrm{DM} \mathrm{ha}^{-1}$ $\mathrm{kg}^{-1} \mathrm{~N}$ over initial harvest dates and levels of applied $\mathrm{N}$ (Table 4). Clearly harvest date by fertilizer interactions have a measurable effect on profitability of fertilization. The importance of this interaction on yield and quality has not been addressed in the economic assessment of meadow fertilization (Taylor et al. 1985, Clark et al. 1991). Mean marginal yield responses from a summary of high elevation meadow trials reported by Taylor et al. (1985) were similar to responses on $15 \mathrm{July}$ at $45 \mathrm{~kg} \mathrm{~N} \mathrm{ha}^{-1}$, but progressively less as rates increased to $135 \mathrm{~kg} \mathrm{~N} \mathrm{ha}^{-1}$. Sedge dominated, prairie meadows appear to be more responsive to high rates of $\mathrm{N}$ fertilizer compared to high elevation meadows. Marginal yield responses to $45 \mathrm{~kg} \mathrm{~N} \mathrm{ha}^{-1}$ for pure stands of Garrison creeping foxtail reported by Power (1985) were intermediate between responses observed in our study on 15 July and 15 August.

In contrast to reduced IVDMD on subirrigated sites in the same location (Nichols et al. 1990), $\mathrm{N}$ fertilizer had no effect on digestibility of herbage from wetland sites in this study. Percent IVDMD of first cutting herbage declined by about .24 percentage points day $^{-1}$ from about $57 \%$ on 15 June to $43 \%$ on 15 August each year,
Table 5. Regression models for IVDMD over a range of initial harvest dates ( $D=$ days after 15 June) for first cutting and regrowth herbage.

\begin{tabular}{ll}
\hline First Cutting & $\mathrm{Y}=56.78-0.2293 \mathrm{D}, R^{2}=.97$ \\
Regrowth & $\mathrm{Y}=52.59+0.0963 \mathrm{D}, R^{2}=.76$ \\
\hline
\end{tabular}

regardless of fertilizer (Table 5). Crude protein concentration in herbage harvested on 15 June increased linearly from $7.5 \%$ at $0 \mathrm{~kg}$ $\mathrm{N} \mathrm{ha}^{-1}$ to $9.1 \%$ at $135 \mathrm{~kg} \mathrm{~N} \mathrm{ha}^{-1}$ (Fig. 1b). In contrast, application of $\mathbf{N}$ had little effect on first cutting CP concentration on 15 July or 15 August (Fig. 1b). Nichols et al. (1990) reported similar N effects on herbage from subirrigated meadow sites harvested from mid-July to early August. Use of $\mathrm{N}$ fertilizer to increase protein concentration in mid- to late June herbage could be efficient even though half of the marginal yield responses to $\mathrm{N}$ had not occurred. Near maximum apparent uptake of applied $N$ in herbage occurred by 15 June, first cutting dry matter yields were generally greater than $4,000 \mathrm{~kg} \mathrm{ha}^{-1}$, and regrowth produced twice as much yield after an initial harvest on 15 June compared with 15 July. Early harvest would also provide forage with higher digestibility (Table 5). Spring-applied $\mathbf{N}$ had no effect on forage quality or yield of regrowth. Total yield from first cutting and regrowth herbage on unfertilized plots was not different among initial harvest dates because of the relatively constant rate at which DM was produced after initial harvest.

\section{Harvest Date $X$ Year}

First cutting dry matter yield increased from mid-June to midAugust in both years, but the rate of increase was more rapid in
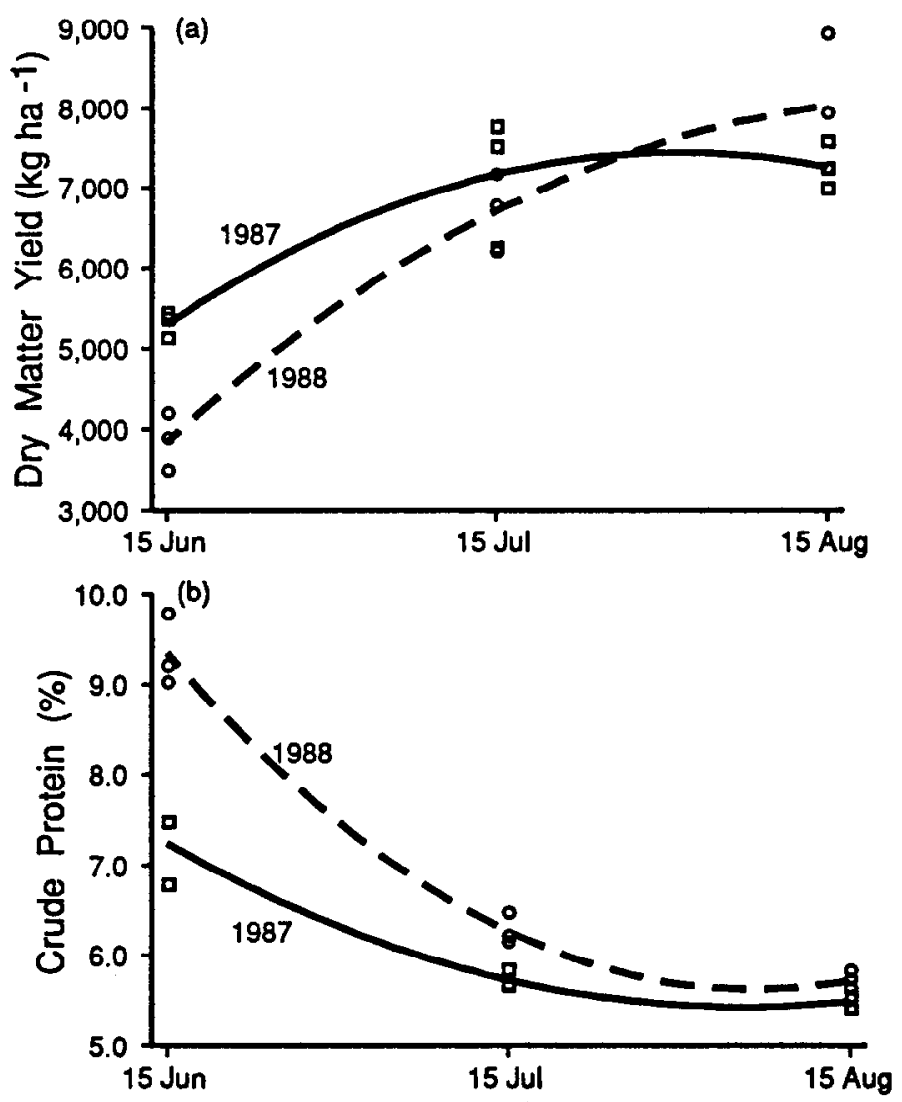

(0)

(30)

(60)

\section{Initial Harvest (Days after 15 June)}

Fig. 2. Initial harvest date by year effects on first cutting DM yield (a) and CP concentration (b). The independent variable (D) is the number of days after 15 June. 
1988 than in 1987 (Fig. 2a). A prolonged period of high DM production in 1988 compensated for the spring delay in plant growth. While crude protein concentration declined more rapidly in 1988 than in 1987, relative differences between years decreased as the initial harvest date was delayed (Fig. 2b). Rumburg and Sawyer (1965) reported an increase in nitrogen content in early July harvested herbage with increasing depth and length of flooding. Based upon regression equations (Table 3) yield in 1988 increased to levels similar to 15 June 1987 , on about 29 June and CP concentration declined to levels similar to 15 June 1987 on about 2 July (Fig. 2).

Initial harvest date by year interactions occurred in yield and protein concentration of regrowth herbage, but the relative magnitude of these interactions was small. Regrowth DM yield decreased by about $39 \mathrm{~kg}$ in 1987 and $47 \mathrm{~kg}$ in 1988 for each day initial harvest was delayed from 15 June (Fig. 3a). Crude protein concentration in regrowth herbage increased as initial harvest date was delayed (Fig. 3b). Mean regrowth CP concentrations for 1987 and 1988
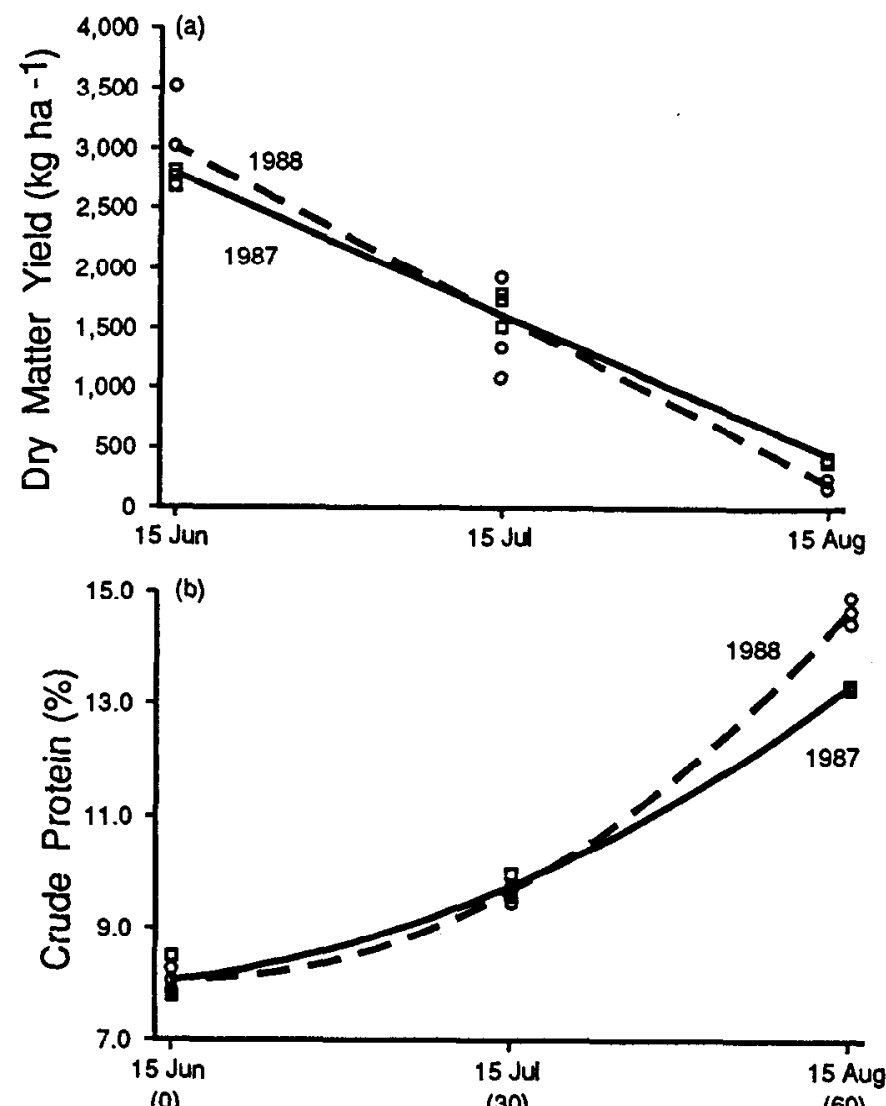

(0)

(30)

(60)

Initial Harvest (Days after 15 June)

Fig. 3. Initial harvest date by year effects on regrowth $D M$ yield (a) and $C P$ concentration (b) harvested in a second cutting on 22 September. The independent variable (D) is the number of days after 15 June.

were within 0.1 percentage point after initial harvests on 15 June and 15 July (Fig. 3b). Given the small amount of dry matter produced after an initial harvest of 15 August, differences in relatively high mid-August protein concentrations between years may be of little practical concern. Changes in regrowth protein concentration corresponded to visual differences in plant maturity.

Digestibility was not affected by differences in duration of spring flooding between years. First cutting IVDMD declined by about 2.0 percentage points for each 10 days delay in initial harvest from 15 June in both years (Table 5). Digestibility of regrowth herbage increased by about 1.0 percentage point for each 10 days delay in initial harvest. The greater rate of change in first cutting IVDMD compared with regrowth IVDMD may have been caused by a greater range in plant maturity in first cutting herbage.

\section{Fertilizer $\times$ Year}

First cutting dry matter yields increased at a diminished rate as level of applied $\mathrm{N}$ increased in both years. However, marginal DM yield response to $\mathrm{N}$ was greater in 1988 with progressively larger relative increases for each $45 \mathrm{~kg} \mathrm{~N}^{-1}$ increment compared with 1987 (Fig. 4). It is unlikely that year by $\mathrm{N}$ interactions were caused

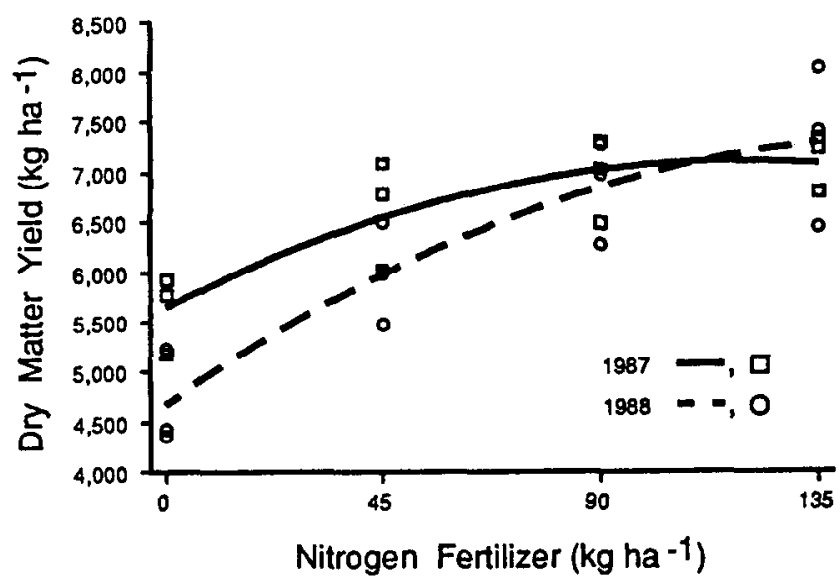

Fig. 4. Nitrogen fertilizer by year effects on first cutting DM yield. The independent variable $(N)$ is the rate of spring-applied $N\left(\mathrm{~kg} \mathrm{~N} \mathrm{ha}^{-1}\right)$.

by fertilizer carryover because spring-applied $\mathbf{N}$ had no effect on second cutting yield or forage quality in either year. The rate of DM production was greater in 1988 than in 1987 during the first and second 30-day periods from mid-June to mid-August (Fig. 2a). Thus, the greater rate of yield response to $\mathrm{N}$ in 1988 appears to have been associated with delayed plant maturity. Soil or air temperatures may have also been more favorable in 1988 than 1987 (Siemer et al. 1972).

\section{Conclusions}

Forage quality, dry matter yield, and response to spring-applied $\mathrm{N}$ were similar for native wetland meadow vegetation and interseeded areas over a range of harvest dates. The primary difference in species composition between native and interseeded plots in our study was the dominance of sedges, a composite of 5 species, and the dominance of Garrison creeping foxtail. Sedge-dominated, prairie wetland meadow sites in this study were more productive than wetland meadows previously discussed in the literature. Unfertilized dry matter yield and marginal yield responses to fertilizer $\mathbf{N}$ were higher compared to high elevation wetland meadows. Chemical suppression of sedge-dominated, native vegetation and interseeding Garrison creeping foxtail could not be economically justified under the conditions of this study.

Regression equations in this text can be used to select efficient combinations of initial harvest date and applied $\mathbf{N}$, including no fertilizer, for wetland meadows similar to this study. Clearly, all possible combinations involve compromises in forage quality or yield. Harvest date by fertilizer interactions have a measurable effect on the profitability of fertilization. Crude protein concentration and IVDMD data from this study provide important information for economic assessment. Forage quality and yield of regrowth herbage are also important economic considerations.

Harvest date decisions have the greatest potental to affect dry matter yield and protein concentrations of herbage between mid- 
June and mid-July. Decisions during this 30-day period appear to be more economically important as the level of fertilizer $\mathrm{N}$ and/or duration of spring flooding increase. Initially low levels of dry matter yield associated with prolonged spring flooding were compensated for by (1) delayed plant maturity, (2) rapid plant growth, and (3) increased marginal rate of yield response to fertilizer $N$.

Decisions for hay production should be based on nutritional requirements of livestock enterprises, total hay costs, and supplementation costs. Wildlife habitat requirements may involve visual obstruction, nutritional quality of forage, and time of availability. Protein supplementation would be required to meet nutritional requirements of most classes of beef cattle when using first cutting hay harvested in mid-July or later from prairie wetland meadows similar to this study (NRC 1984). First cutting hay harvested by mid-June and fall grazed regrowth produced on meadows after a mid-June harvest date would generally meet maintenance and gestation requirements of dry cows. Regrowth after an initial harvest in mid-July or later would meet nutritional requirements of most classes of livestock, but provide half or less as much dry matter compared to regrowth after an initial harvest on $15 \mathrm{June}$.

\section{Literature Cited}

Anderson, B.E., K. Hladek, and R. Kanable. 1990. Certified perennial grass varieties recommended for Nebraska. Univ. Nebraska Coop. Ext. Serv. EC90-120.

Association of Official Analytical Chemists. 1975. Official methods of analysis (12th ed.). AOAC, Washington, D.C.

Chancey, E., W. Elmore, and W.S. Platts. 1990. Livestock grazing on western riparian areas. US Gov. Print. Off. 775-443/21,661 Region 8.

Clark, R.T., J.T. Nichols, and K.M. Eskridge. 1991. Economic optimum fertilization rates for subirrigated meadow hay production, including values for hay quality. J. Prod. Agr. 4:233-240.

Dodds, D.L., and E. Vasey. 1985. Forages for salt-affected soils. North Dakota State Univ. Coop. Ext. Serv. R-584 Rev.

Fairbourn, M.L. 1982. Water use by forage species. Agron. J. 74:62-66.
Gomm, F.B. 1978. Growth and development of meadow plants as affected by environmental variables. Agron. J. 70:1061-1065.

Great Plains Flora Association. 1986. Flora of the Great Plains. T.M. Barkley (ed.). Univ. Press of Kansas. Lawrence.

Laughlin, W.M., G.R. Smith, and M.A. Peters. 1984. Influence of N, P, and $\mathrm{K}$ fertilization on yield and mineral composition of native bluejoint grass on the lower Kenai Peninsula, Alaska. Agron. J. 76:389-397.

Marten, G.C., and R.F. Barnes. 1980. Prediction of energy digestibility of forages with in vitro rumen fermentation and fungal enzyme systems. $p$. 61-71. In:W.D. Pigden et al. (eds.) Standardization of analytical methodology for feeds. Int. Devel. Res. Cent., Ottawa, Can.

National Oceanic and Atmospheric Administration. 1988. Climatological data (Nebraska). Asheville, N.C.

National Research Council. 1984. Nutrient requirements of domestic animals. No. 4. Nutrient requirements of beef cattle. 6th rev. ed. Nat. Acad. Press, Washington, D.C.

Nichols, J.T., P.E. Reece, G.W. Hergert, and L.E. Moser. 1990. Yield and quality response of subirrigated meadow vegetation to nitrogen, phosphorus, and sulfur fertilizer. Agron. J. 82:47-52.

Power, J.F. 1985. Nitrogen-and water-use efficiency of several cool-season grasses receiving ammonium nitrate for 9 years. Agron. J. 77:189-192.

Power, J.F. 1986. Nitrogen cycling in seven cool-season perennial grass species. Agron. J. 78:681 687.

Power, J.F. 1988. Seasonal changes in smooth bromegrass top and root growth and fate of fertilizer nitrogen. Agron. J. 80:740-745.

Rumburg, C.B., and W.A.Sawyer. 1965. Response of wet-meadow vegetation to length and depth of surface water from wild-flood irrigation. Agron. J. 57:245-247.

Siemer, E.G., G.O. Boatwright, and C.B. Rumburg. 1972. Forage yield and forage quality on scattered mountain meadows. Colorado State Univ. Exp. Sta. PR 72-15.

Snedecor, G.W., and W.G. Cochran. 1967. Statistical methods ( $6^{\text {th }}$ ed.). Iowa State Univ. Press, Ames.

Stroh, J.R., J.L. McWilliams, and A.A. Thornburg. 1978. 'Garrison' creeping foxtail. SCS USDA, SCS-TP-156.

Taylor, D.T., W.J. Seamands, D.J. Menkhaus, J.J. Jacobs, and R.H. Delaney. 1985. An economic analysis of $\mathrm{N}$ fertilization on intermountain hay meadows. Agron. J. 77:17-20.

Welty, L.E., R.L. Anderson, R.H. Delaney, and P.F. Hensleigh. 1981. Glyphosate timing effects on establishment of sod-seeded legumes and grasses. Agron. J. 73:813-817. 